\title{
COLONNADED STREETS WITHIN THE ROMAN CITYSCAPE: A "SPATIAL" PERSPECTIVE
}

\author{
Shaher RABABEH ${ }^{a}$, Rama AL RABADY ${ }^{b}$, Shatha ABU-KHAFAJAH ${ }^{c}$ \\ Department of Architectural Engineering, Hashemite University, Zarqa, Jordan \\ E-mails: ${ }^{a}$ srababeh@hu.edu.jo (corresponding author); ${ }^{b}$ ramarabady@gmail.com; ${ }^{c}$ shathaa116@gmail.com
}

Received 17 June 2014; accepted 20 November 2014

\begin{abstract}
Studies tackling the Roman legacy of colonial cities and Arabian provinces are still grappling with these cities from an urban planning perspective and/or building typologies. They do not provide a 'spatial' analysis that allows reading the Roman cities through the features that structured its urban language; one of which is the colonnaded streets. The study adopts a holistic approach to confront the ambiguities about possible origins, uses and meanings of the Roman colonnaded streets when traced in the Roman East as well as other Western cities. Besides its utilitarian and cultural value, the colonnaded streets are nalyzed according to two interrelated interpretations: astrological interpretation to represent an empire of astral divinity and performative interpretation to represent an empire of imperial power. The colonnaded streets is transformed from a 'line on site' into a 'line of sight' that testifies to the social norms of the Roman people but also to their ideologies, beliefs, and aspirations.
\end{abstract}

Keywords: colonnaded streets, Roman urbanism, spatial analysis, astrological interpretation, performative urbanism.

\section{Introduction: the colonnaded streets as an urban discourse}

Most urban studies tackling the Roman legacy of colonial cities and Arabian provinces are still grappling with these cities from an urban planning perspective and/or building typologies. Discussions could be grouped within two umbrella themes: planned versus unplanned Roman cities, and standardized versus adaptable planning schemes.

As per the planned versus unplanned Roman cities, analyzing the formalization of Roman cities is usually made through distinguishing between the geometrically planned and the organically unplanned cities. The classification is mainly tackled from a political point of view. It depends on the norms of creating new cities, increasing the size of existing ones or refurbishing existing cities according to Roman standards ${ }^{1}$. Cities

1 Cavaglieri (1949) used three relevant classifications for the design adopted by the Romans for their cities in Europe, North Africa, and the Middle East. They include cities grown up without general pre-planning; existing cities transformed into Roman colonies; and cities grown out of military camps. of this typology are analyzed based on the layout of the streets (main and secondary) and the divisions of the city's functional zones. Some scholars suggest that streets in unplanned cities emerge gradually according to the needs and expansion of the city (Segal 1997:5; Cavaglieri 1949). They are randomly distributed with open spaces that serve the free movement of people and goods. Nevertheless, these cities are based on zones and districts that have uniform character, such as the capital city of the Roman Empire, Rome and, to some extent, Ostia. The opposite situation is experienced in planned cities, including colonies that are adyorganized or cities grown out of military camps. Cities feature street layout that is designed according to an urban program and prior to laying out the city's zones, buildings and other functional divisions. They are described as 'regular', 'geometrical', 'grid' or the 'castrum' plans.

For many other scholars, 'standardized versus adaptable city planning' is the main criterion for analyzing the urban morphology of Roman cities. Notions 
of 'typical' Roman city, 'ideal' Roman city, and 'standardized' Roman city are widely used in literature when describing the characteristics ordering urban spaces in these cities (Zanker 2000; Segal 1981). The phenomenon of standardization in Roman urbanism is mainly approached through the use of accepted and conventional standards of city structures and decorations and repeating them in different settings to generate standardized urban scenes. Most distinguished in the Roman cities is the 'strictly axial-symmetrical grid of streets' that emphasizes standard point of reference where sacred and political spaces are united within the central forum.

Centralized plans eventually evolved in Roman cities as a 'fashionable' trend that could be copied in other important areas, including urban Arabia. Segal (1981) suggests that although cities in this region were competing with one another, they nevertheless copied styles in an attempt to keep up with the modest architecture of that time, as the cases of Philadelphia and Gerasa. Besides copying building structures, the Romans used a dominated skeleton-like urban structure that acted as the backbone of the city; that is the castrum with its colonnaded streets. The basic standards of the castrum layout were enforced even in difficult climatic and geographical conditions; as the cases of Augusta, Timgad, Silchester, etc. (Cavaglieri 1949: 41). The colonnaded streets ultimately evolved as central axes with similar width, intercolumniations, and standard form of capitals (ionic or/and Corinthian) ${ }^{2}$. Sartre supports this discourse and suggests that "[t]he colonnaded streets tended to mask the public buildings behind them and to standardize the landscape" (Starte 2005: 183).

Theory of standardization in the Roman urban planning has been justifiably refuted by some scholars. MacDonald (1982: 19) discusses the urban armatures in Roman cities and suggests that "...no two armatures are alike; they are as different as the cities and towns. The monotonous regularity sometimes attributed to Roman towns is a myth with respect to the empire, for though some Republican and Augustan colonies had been planned according to the generalized formula, subsequent expansion and the almost inevitable addition of the familiar but varied imperial amenities relaxed the formula's rigidity". Alternatively, the Romans were able to adapt and bring into their own civilization what previous or existing civilizations had developed. On one side, adaptation was related to the fact that the Romans were

\footnotetext{
2 Mostly the capitals of the colonnaded streets were of similar typology, except in some places were the colonnaded is suggested to develop in different periods as the case of Gerasa where the colonnades were first Ionic and later changed into Corinthian.
}

not able to copy their original city, Rome, and consider it a role model because of the slow and unusual changes that occurred to this city during the different imperial eras (Zanker 2000:26). On another side, adaptation occurred because the Romans grew more interested in developing and enlarging existing cities than establishing new towns - A phenomenon that was particularly noticed in styling and planning of the Greek or Hellenized cities in Arabian areas (Segal 1981).

Buildings in Arabian area were constructed and decorated to suit local building materials, methods and the urban scene of an Arabian city. As in other colonies, these buildings were used alongside other familiar Roman urban furniture (such as the arches, fountains, baths, etc.) in order to enhance the sense of urban pride and community cohesion (MacDonald 1984). Segal even went further in this adaptation theory and suggests that "Rome contributed little to the urban architecture in this area [the Province of Arabia], acting more as a catalyst, creating the right conditions for the growth and prosperity of the local architecture.... The Romans did introduce a few new structures into the area, but these soon lost their original use and character and were subsequently styled in the manner of Arabian urban architecture"(Segal 1981: 15) . $^{3}$

So far, it could be realized that the focus of discussions on the Roman urban cities, including those in the Province of Arabia, is still revolving around two main dichotomies: planned as opposed to organic city forms and standardized as opposed to flexible Roman planning culture. In due course, these discussions tackle the Roman city from an urban planning perspective. They are more concerned with the common qualities and symptoms that characterizes the overall urban image of the Roman cities (the whole) and not with the components that make up the urban structure of the city (the parts); one of which is the colonnaded streets. Current study suggests that town planning involves more. It is tightly connected with the urban design studies which recommend that urban-related studies should concern itself with the nature of its urban features that make up these urban settings but also provides for the creation of functional, visually pleasing, and meaningful urban spaces.

\footnotetext{
3 In other instances, theory of adaptation was related to the geographical factor. Some scholars suggested that the urban plan of cities was determined by existing topographical conditions of the selected site. In the case of Philadelphia, for example, the temples were constructed upon the acropolis and the public buildings were distributed along the two colonnaded streets that run along the existing valleys (Hadidi 1970; Segal 1981). Similar situation is noticed in cities such as Ostia, which has been described as a typical 'lineal' city, along with many other cities that failed to apply the castrum scheme because it featured complex topographical and natural attributes.
} 
Similar approach has been previously advocated by MacDonald who suggests that analyzing urban armatures should not be confused with city planning. According to him "[c]ity planning is a comparative study, but armature analysis is the opposite, for it starts with essential comparisons already made- the presence of common qualities and features- and proceeds to the investigation of their several levels of relationships"(MacDonald 1982: 25). Equally important, and since the colonnaded streets are considered essential component of the urban armatures in the Roman culture, analysis of this urban feature should focus on its own characteristics in order to be able to relate it to the wider urban landscape. Although some studies exclusively tackled the Roman colonnaded streets and sought to identify its origin, functional purposes, and aesthetic value (see for example (Segal 1981; 1997; Burns 2011a; 2011b; MacDonald 1982; 1984), these studies were not able to comprehensively deal with the colonnaded streets through a holistic approach, i.e., as an urban and spatial entity. Our study is intended to achieve this goal through investigating the different theories that have been suggested for determining the origin of the colonnaded streets and relate these theories to the ideological dimensions and theoretical approaches that supported its use as a major component of the urban landscape in the Roman culture.

The study starts by identifying the form and function of the colonnaded streets with considering different examples from the Roman East cities. It then discusses the different discourses about the origin(s) of the colonnaded streets. Based on that, different theories for the use and meaning of the colonnaded streets are analyzed. The study concludes by stressing the 'spatial' attributes of the colonnaded streets in the place making of the Roman cities, especially those in the Eastern provinces.

\section{Colonnaded streets: definition and form}

Roman cities were widely built as a result of the political power and economic changes that happened after the extension of the Empire to the East. East cities, as many other Roman cities, were generally divided into squares or rectangles through delineating two main streets that seemed to follow some pattern of orientation. In most cases, the streets were flanked by columns on both sides to form what came to be known as the 'colonnaded streets'. They are defined as "streets with colonnades along their full length extending on either side... and generally ran in straight, uninterrupted lines across the length and breadth of the city, connecting the different urban centers" (Segal 1997: 5). These two colonnaded streets evolved as the main thoroughfare axis in the Roman city (Segal 1997) and a major component of its 'urban armatures' (MacDonald 1982). Parallel to them, secondary streets were laid out in the form of a chessboard and public and private buildings were also distributed among the delineated geometrical streetscape (Haverfield 1913: 77). Layout and number of the streets depended on the size of the city and the morphology of its topography.

The colonnaded streets remain one of the most impressive and memorable parts of the Roman East cities (Fig. 1). One of the most distinguished examples is the colonnaded streets of Palmyra. Palmyra lies further east in the Syrian Desert, on the edge of the Fertile Crescent that links Syria and the seacoast with Mesopotamia in the east ${ }^{4}$. The main colonnaded streets, acting once as the major economic artery, run from the great temple of Bel, which lies in the southeast end of the city, to the northwest. The exedra lies in the southern side of the street. At the northeast corner of the Sanctuary of Nebo the street changes its direction, where the transverse arch of wedgeshaped lies. From this intersection point the street runs northwest until it reaches the piazza, which is oval in shape and in its centre is a Tetrakionion or the so-called Tetrapylon. Before reaching this area, the Nemphaeum lies to the north side of the street. However, the street changes its direction at the Piazza and runs in a straight line to the northern side of the city (Owens 1991: 144; Tomlinson 1992: 206). The lavish porticoes of the street are adorned with statuary, shops, and the majority of public buildings. The street is flanked by Corinthian columns and walkways opened to shops on each side. Columns are marked by similar ornament, column size and coloured stone in order to allow visual continuity in the urban scene. In some cases, however, taller columns were supplied in order to distinguish and emphasize the presence of major buildings along the colonnaded streets (Butcher 2003: 248; MacDonald 1982: 44).

One of the best well preserved colonnaded streets is found in the ancient city of Gerasa, known today as Jarash in Jordan (Fig. 1). The first Roman plan of the city was established in the second half of the first

\footnotetext{
4 The site of Palmyra played an important role in the commercial history of the Roman east. It connected the main north south and the east west trade routes passing through the area. It was incorporated into the Roman province in the first century C. E. As a result, the city became wealthy and its wealth was mainly represented in its urban fabric, specifically the colonnaded street that once acted as the major economic artery.
} 


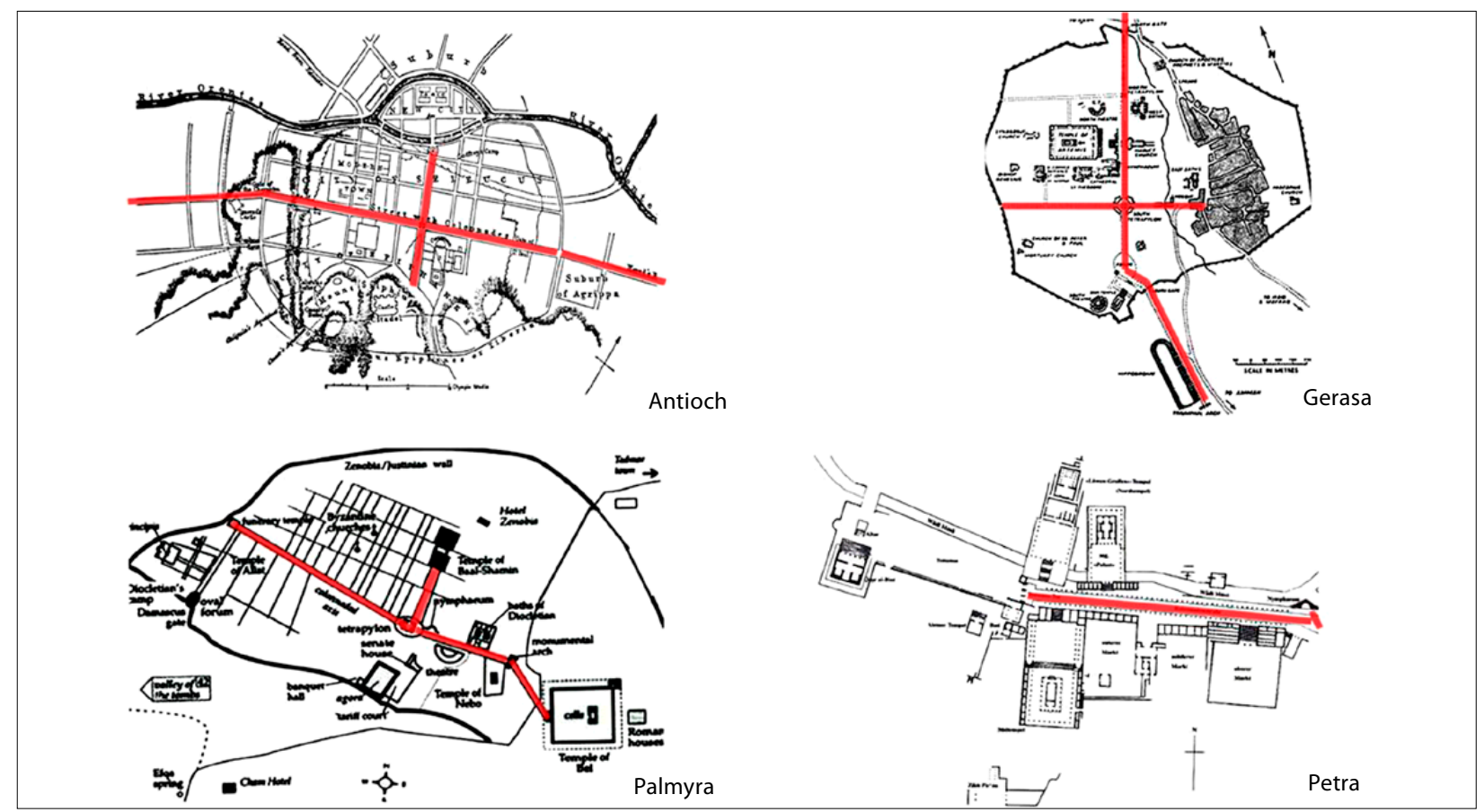

Fig. 1. The colonnaded streets as appeared in the Roman East cities of Antioch, Palmyra, Gerasa, and Petra. Sources: modified from http://www.bible-history.com/ibh/Geography,+Plans,+Maps/Syria/, http://www.computer-render.com/Pages/Gerasa_2.html, http://www.lems.brown.edu/shape/Presentations/Vote99Nov12/Board1/mages/CityCenter.jpg).

century C.E. (Kraeling 1938: 36, 39; Khouri 1986: 6)5. The layout of the city is delineated along the colonnaded main streets, the Cardo and the two intersecting colonnaded Decumani, dated to the sixties of the first century C.E. (Kraeling 1938: 42). The Cardo runs northsouth in the west bank parallel to the Wadi Chrysorrhoas, which divides the city naturally into two unequal portions, to reach the western part of the city where most public buildings lay ${ }^{6}$. The Cardo changes its direction after entering the south gate, where the oval piazza is built to emphasize the presence of this change. The piazza is considered the busiest commercial area in the city. The decumani intersects the cardo at different points. The southern intersection is marked by the south Tetrakionion, which is built in a large circular space surrounded by shops and the northern intersection was marked by the north Tetrakionion (Sear 1982: 252; Khouri 1986; Owens 1991: 142). The normal

\footnotetext{
5 The city belonged to the new Province of Arabia, which was founded by Trajan after the annexation of the Nabataean kingdom in 106 C.E. It was situated off the Via Traiana Nova, which was the most important route linking the Roman West with the East. It achieved a great wealth by participating in the international trade. The real golden age of Gerasa was under the Antonines, which was characterised by the construction of different architectural monuments (Kraeling 1938: 42).

6 This part continued to be public and residential in the Byzantine and Islamic Period (Zeyadeh 1985: 203).
}

arrangement of the street includes a sidewalk on both sides, from which steps led up to the covered porticoes and incorporated the colonnades. Corinthian and Ionic columns were used. They have the same height throughout the street, but close to the intersection and the main gate way taller columns appear. Buildings are distributed along both sides of the main streets, but they do not disturb the continuity of the colonnades.

Similar characteristics of the colonnaded streets are found in other Roman cities in the east such as Philadelphia, Bosra, Apamea, and Petra (Fig.1). Although, they differ widely from place to place in size, plan, orientation, and in degree of urban complexity; they are all morphologically and conceptually related.

\section{Colonnaded streets: debating originality}

Practically, the colonnaded streets gave a structure to the Roman city and connected its major buildings within a unifying urban scheme (MacDonald 1982: 50, 51; Mango 2001: 30). Different hypothesis have been developed for determining the possible origins and genealogy of the colonnaded streets. In discussing these hypotheses, it has been mostly referred to the colonnaded streets as almost entirely limited to Eastern provinces. MacDonald (1982: 44) does not completely support this claim and declares that the colonnaded streets have been found at many western 
sites also. Accordingly, the origin of the colonnaded streets can be discussed as an urban element that could have been descending from different civilizations, including the Greek, Etruscan, and Eastern civilizations.

\section{Greco-Etruscan origins}

For several scholars, Roman city planning in the East is considered a natural extension of the Greek school, and subject to Hellenistic influences (Haverfield 1913: 77; Rostovtzeff 1926: 149; Woloch 1983: 10-11; Pregill et al. 1999: 126-127).Greek cities were naturally evolving during the early years of Athenian democracy in the $5^{\text {th }}$ century B.C.E. and were seen in the form of the Hippodamus's Miletus plan (Kostof 1991: 106). Meanwhile, the Greek succeeded in founding new cities in the East. When their power weakened, their cities were eventually taken over by the Romans who re-founded and conserved the continuity of the Hellenistic city planning. After the conquest, the Romans provided the peace and prosperity essential for the successful growth of the cities. They also supported the Hellenized cities in the area economically and politically (Segal 1975: XV).

The Romans thus inherited and built upon the previously established Greek and Hellenistic traditions. ${ }^{7}$
The 'Hippodamian' gridded cities remained a widespread feature of the Greco-Roman world (Owens 1991: 6; Cavaglieri 1949). Alongside the city form, it has been argued that the Romans borrowed other urban features from the Classical Greek, specifically the Greek Stoa. The stoa dates to the late $7^{\text {th }}$ century B.C.E.; originating in cities such as Didyma, Smyrna, Samos, and Argos. It is "planned as freestanding buildings with long, narrow plans and had both an inner and outer colonnade. The long back wall was often divided into individual rooms corresponding in width to the columns bays"(Stamper 2005: 88). With reference to the Greek stoa, Vitruvius described the Roman portico as a construction that "have two aisles, with Doric columns on the outside, and that their architraves and ornaments should be finished according to the law of modular proportion. The width of each aisle should be equal to the height of the outer columns.

The inner row of column should be one-fifth higher than the outer row and should be designed in the Ionic or Corinthian style (Morgan 1914: 154). Accordingly, it has been argued that the Roman colonnaded streets acts as an elongated stoa (Fig. 2), i.e., a trade or market strip (Coulton 1976: 177; Mango 2001: 30). The Romans

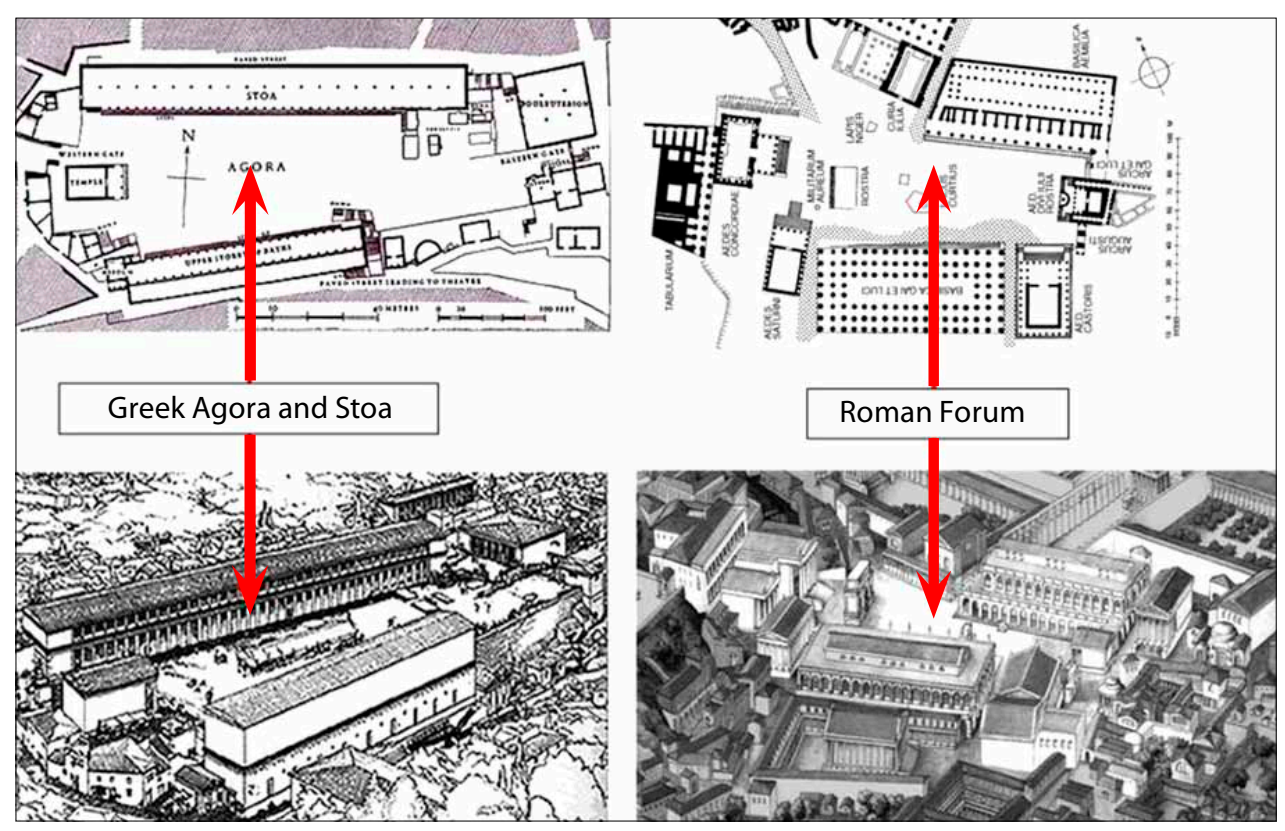

Fig. 2. Assos agora with its double-storey Doric order and a temple built in the $2^{\text {nd }}$ century (left) compared with the first Forum Romanum that formed similar architectural forms and spatial alignment but with different functions (right). Source: modified from http://www.exploreturkey.com/ asos.htm, andhttp://www.wiw.pl/kulturaantyczna/twardecki/pict/zoom/Romaet44.gif

\footnotetext{
7 When Octavian was granted the name of Augustus, Vitruvius presented him with a copy of his 'Ten Books on Architecture' and "urged him to design his public buildings with dignity and authority consistent with the Hellenistic East" (Stamper 2005: 107). Vitruvius' books were able to synthesize the Hellenistic tradition of Hermogenes and Hermodorus into a codified system of building that would influence Roman architecture. In line with its architectural richness, the Hellenistic East was distinguished in its urban planning and design treatment.
} 
borrowed the form of this urban feature, but also its function as a shelter from the sun and as an urban space that incorporates the market zone in the Roman city.

When analyzing the colonnaded streets from a Greek-based perspective, we might be confined to the 'functionality' and 'formality' of the colonnaded streets whilst undermining its symbolic value in the making of the Roman East cities. MacDonald (1984) advises us to broaden our scope when studying the Roman design and "discard misleading assumptions such as the belief that all Roman design is based on Greek precedent, or that Vitruvius helps us to understand fully characterized Roman architecture". Magli (2008a) also did not fully support the interrelation of this type of layout to military camp (castrum) or the Hellenistic orthogonal town planning. Knowing that, it could be acceptable to suggest that although the colonnaded streets evolved as a natural outgrowth of the form and function of Greek stoa, other sources of inspirations could have existed in former civilizations and affected the form, function and meaning of the colonnaded streets, including the Etruscans who created the first visible civilization in Italy and were developed during the 700s B.C.E. into a series of autonomous city-states; one of which was Rome. The hypothesis is widely accepted in literature because when the Romans conquested Italy, cities and towns were mostly recognized by an orthogonal plan which was developed from two main axes.

Whilst the Greco-Etruscan hypothesis for determining the origin of the Roman colonnaded streets remain instrumental in the classic literature, it should not be forgotten that the colonnaded streets, and although it appeared in many sites of the Western provinces as in Stobi, Lepcis Magna, Timgad, Djemila, and Vaisonla-Romaine (MacDonald 1986: 44), it remained less essential in the Western provinces and Rome itself. The many porticoes and fora fulfilled the same purpose in these places (Plommer 1956: 315; MacDonald 1982: 82). Vitruvius himself approached the porticos and the city streets as two separate entities and gave each its functional and formal attributes. It was in the East where these two entities were fully integrated with each other to form a colonnaded street. If this claim is considered, it could be plausible to trace potential origins of the colonnaded streets in the East, as will be discussed in the next section.

\section{Eastern origins}

Segal (1981: 17) declares that the norms of the classical architecture in Roman cities in the Province of Arabia could have been influenced by the native Arabian town planning in this region. Cities were not necessarily con- fined to the limitations of the Hellenistic and Roman town planning. It is an assumption that allows us to associate the Roman East cities with the long history of established ancient cities in this region where an urban life antedates by several centuries the emergence of cities in the Greek and Roman world (Owens 1991: 1).

In general, studies tend to relate the origin of the colonnaded streets to Asia Minor. It was found throughout this region by the $2^{\text {nd }}$ century B.C.E. (Ward-Perkins 1974: 32, 1979: 165) or during the end of the $1^{\text {st }}$ century B.C.E. (Segal 1981: 7). It is suggested that the first true colonnaded streets, which set the fashion of the colonnaded streets is the one built by Herod the Great at Antioch at the end of the $1^{\text {st }}$ century B.C.E. (Bosanquet 1915; Coulton 1976: 179; Haverfield 1913: 105; Butcher 2003: 247) ${ }^{8}$. From that date onwards, the model spread widely in the eastern Mediterranean. It became a reference point for the Roman East city planning; in a matter that any city without colonnaded streets was considered poor (Ward-Perkins 1974: 32). Many examples are found at other towns of Syria ${ }^{9}$ such as Palmyra, Gerasa, Bostra, Philippopolis, Apamea, Damascus, Samaria, Jerusalem, etc.

Other earlier and possibly relevant cases are found in the Mesopotamian and Egyptian civilizations. An axial colonnaded wall appeared throughout the Procession Street of Babylon which served as the nor thern entrance way into the city. It ran through the Ishtar gate which adorned Babylon during the reign of Nebuchadnezzar II (605-562 B.C.E.) and led through the inner city to the Madurak sanctuary to end at the bridge across the Euphrates (Fig. 3). It was partially decorated with reliefs of lions to welcome the procession of the New Year's festival through which the king, members of the court, priests and statues of the gods travelled to the 'Akitu' Temple ${ }^{10}$. Similar path in the Egyptian landscape is found at the phoenix avenue in Luxor that was built by the King Nectanebo 380-343 B.C.E. According to recent excavations, the avenue incorporates 90 sphinxes and stretches about two and a half kilometres to connect Luxor Temple with the temple complex of Karnak.

\footnotetext{
8 MacDonald (1982: 44) did not support the claim that the earliest example of the colonnaded street was built at Antioch on the Orontes of Herod about 30/20 B.C. E. because " $\mathrm{t}]$ he main street was paved as Herod's 43 order, but the roofed colonnades beside it were probably built in the time of Tiberius".

9 According to Bosanquet (1915), Syria must be understood to include Palestine and the borders of Arabia.

10 Within this same period, a similar model of the processional path has been found in the Terrace of Lions found in the sacred city of Delos (or Dilos in Modern Greek). The terrace was dedicated to Apollo by the people of Naxos shortly before 600 B.C.E. It features number of snarling marble guardian lions (probably 16) along the Sacred Way.
} 


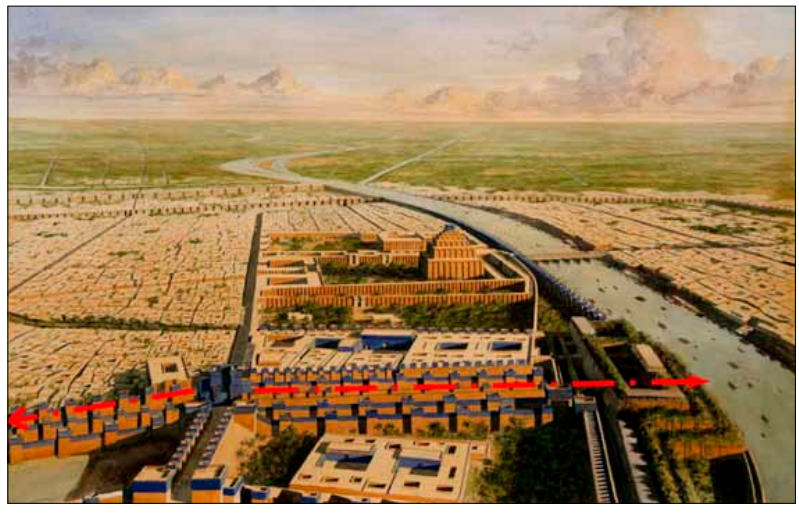

Fig. 3. Main processional street (Aj-ibur-shapu) towards Ishtar Gate in Babylon. Sources: Modified from: http://www.cristoraul. com/ENGLISH/The-Book-of-History/Volume-1/32-RISE-OFCIVILISATION-IN-MESOPOTAMIA.html

The two examples thus introduced the concept of a monumental avenue- an image that can be related to the Roman colonnaded streets if approached as processional path - as will be discussed later in this study with more supportive examples.

If the abovementioned hypothesis about the origin of the colonnaded streets are considered comprehensively, it might be difficult to determine which civilization(s) had presumably influenced the Roman colonnaded streets the most, especially that the Romans, and before them the Greek and Ptolemaic civilizations ${ }^{11}$, were in direct contact with these regions. This is not to suggest that the Romans copied a standard form from specific civilization(s) and abstractly incorporated it into the design of their cities. Rather, the study outlines the potential origin(s) for the colonnaded streets in order to use it as a framework for analyzing the possible spatial qualities, uses and meanings of the Roman colonnaded streets as an ancient legacy.

\section{The colonnaded streets: a spatial perspective}

Old literature tends to describe the 'technical' use of the streets to achieve functional harmony. In his study on the "Ten books on Architecture" Vitruvius emphasized the role of the streets in creating 'healthy', 'pleasing' and 'safe' movement within the Roman cities. For him, it was important to lay out the lines of streets and alleys with regard to climatic conditions. Meanwhile, they should be designed as thoroughfares where the space in the middle, between the colonnades and open to the sky, is embellished with green things to give clean-cut images and ornamented walks. Their

\footnotetext{
${ }^{11}$ In 539 B.C.E., Babylon would fall to the forces of Cyrus the Great, who incorporated the city into the Persian Empire. About two centuries later, the city would fall again to Alexander the Great, who made it the capital of his own empire. The city collapsed after his death in 323 B.C.E.
}

functional and aesthetic values are shared with other architectural and spatial treatments in the city, especially the colonnade in front of the temples or in the theatres behind the scaena.

According to this technical approach, an instrumental rationality is suggested (Morgan 1914) to embody human needs and aspirations, mainly from architectural and planning points of view. It thus reduces Roman cities into an urban realm composed of blocks of buildings with streets around them. Alternatively, plausible socio-cultural interpretation arose in later literature and approaches the colonnaded streets as a metaphoric representation of the Roman people residing outside Rome, i.e., as a means of Romanization. Essentially, the hypothesis relies on two premises. The first is that the Romans were able to modify existing plans of colonized cities according to urban modules of Roman cities in order to send political messages about their existence and imperial power (Stirling 2006). The second concerns itself with urban movement which was embedded in Roman habits of thought that it could have turned into a metaphor outside Rome. Constructing the colonnaded streets with this monumental scale and direct visual expression gave a metaphor of flow and connection with the home city of Rome (Zanker 2000). Whilst inside Rome, the monumental summits of the Capitol and the Palatine, with the Temples of Jupiter, Juno Moneta, and Isis, imperial residence, and places of public resort stood out on the skyline of the capital city of Rome; it was the colonnaded streets that dominated the cityscape outside Rome. Its grandeur monumentality grew out of the importance assigned to become a place through which the Romans could appreciate who and where they are. In other words, the colonnaded streets were envisaged as a means to overcome a predominating sense of 'fragmentation' and 'alienation' for Romans settling outside Rome.

Besides the technical and cultural approaches for interpreting the use and meaning of the colonnaded streets in the Roman East Cities, current study, and based on old theories along with contemporary findings, suggests a 'spatial' reading of this urban entity in order to be able to uncover other possible meanings and uses that are not addressed in literature yet. Two interrelated themes are considered accordingly: astrological interpretation and performative interpretation.

\section{Astrological interpretation to represent an empire of astral divinity}

Architecture-by-astronomy, or building with the stars, was familiar in the ancient world (Magli 2008a). Ancient kings and rulers tended to build their cities and architecture with considering the stars and their 
constellation. Mostly cited is the architectural experience of the Egyptians who associated the sun god Ra with their pharaohs and built their pyramids accordingly (for example see the Great Pyramid of Giza that was aligned along the compass points of the stars). But the earliest written sources dealing with astronomy came from Mesopotamia - the regions of ancient Assyria (mainly Nineveh) and Babylonia (mainly Babylon, and Uruk and to some extent Sippar, Nippur and Ur) (Ruggles 2014). Their astronomical and astrological learning were transmitted to other cultures in the second and first millennia B.C.E. (Jones 2015: 1877; Ruggles 2015: 1629). In particular, and following the Macedonian conquest, the Greco-Roman world was influenced by the Babylonian astral sciences, urbanism, literacy, and statecraft (Rochberg 2010). Besides the quantitative methods and parameters (i.e., mathematical astronomy), the Babylonian astronomy was ideologically influential to these cultures as it "came as a part of complex set of ideas, including the divine nature of the heavenly bodies or the idea that the reciprocity between heaven and earth manifested in celestial signs" (Rochberg 2010: 10).

Understanding the ideological cosmological reference of ancient settlements of these civilizations is best managed through the old theories of "celestial archetypes" and "symbolism of the center" that were best explained by Eliade (1954: 6-21). According to the "celestial archetypes", creation of territories, temples, and cities is an imitation of a celestial archetype. Cities followed divine prototypes and extraterrestrial archetype in the form of plan, geometry, or even metamorphically as a 'double existing on a higher cosmic level'. It was supposed that initiating a settlement on a virgin, uncultivated, chaotic territory is an act of "transformation of chaos into cosmos by the divine act of Creation". According to this idiom, the territory was first 'cosmicized' through rituals to give it a 'form' and put it on order to become inhabited by people. Ancient Babylonian cities (especially Babylon which means Bãb-ilāni, a "gate of the gods"), the celestial Jerusalem, Indian Royal cities, evolved as clear examples of the ancient cities that followed extraterrertrial prototype.

Cities of this typology grew with orthogonal layout (or centuriated landscape, to use the term of Palet and Orengo (2011)) that equated the workings of cosmos and life on earth. The basic link between earth and cosmos was made through architectonic means that assimilate to the 'centre of the world', i.e., "symbolism of the centre". Features included the Sacred Mountain, temples, palaces, sacred cities or royal residences. On an urban level, however, the basic link between earth and cosmos was the axis mundi; according to which the cosmos, and the cities consecutively, were laid out in four cardinal directions. Theoretically, the cardo was related to the axis mundi and was oriented north-south and the decumanus was connected with the path of the sun and was oriented east-west (González-García, Magli 2015). In Roman culture, the axis mundus symbolized the center because "Among the Romans,... the mundus - that is, the trench dug around the place where a city was to be founded - constitutes the point where the lower regions and the terrestrial world meet"(Eliade 1954: 15-16). With reference to axis mundus, the orthogonal layout of the Roman towns was generally quadripartite.

'Celestial archetypes' and 'symbolism of the centre' required divination and augury to identify the sacred space on earth (Eliade 1954; Smith 2007). According to a variety of ancient resources and literature, the Roman city planning was initiated with "ritual procedures inherited from the Etruscans and closely connected with the equipartition of the Cosmos according to cardinal directions" (González-García, Magli 2015: 1644). These rituals required astronomical orientation in order to be able to identify the terrestrial image of the heavens (templum) in which the gods were cardinally oriented (the auguraculum). Believing in the 'repetition of the Creation', similar rituals were used in different occasions at both the architectural (i.e., building or complex of buildings) and urban levels (i.e., entire city) because, as (Eliade 1954: 18)suggests, "every creation repeats the pre-eminent cosmogonic act, the creation of the world...[and] consequently, whatever is founded has its foundation at the center of the world", i.e., the act of creating buildings and cities is connected with an idea of creating a sacred space.

In several occasions, Giulio Magli, an archaeo-astronomer at the Politecnico of Milan, and many other scholars, sought to assess the astronomical relevance and cardinal orientation in the planning of Hellenistic, Etruscan, and Roman cities. As per the Etruscan and based on the rounded stone with an inscribed decussis (cross) that was found under the foundation of layer of the street of the Etruscan city of Misa, Magli suggests that the whole urban layout of the city may have been conceived as a templum, "in which the eight main street crossings...played the role of the eight stone cylinders of the Bantiaauguraculum" (Magli 2008b: $150)^{12}$. In the ancient city of Alexandria which was found by the Macedonian king Alexander the Great in 331 B.C.E. Magli suggests that the city was neither planned in accordance with the existing topograph-

\footnotetext{
12 Mansuelli (1979: 359-360) also provided the evidences that Etruscan cities evolved from a town-planning theory and not simply of an empirical approach. The axial layout was primarily the result of peculiar religious beliefs of the Etruscans. It was based on marking out a templum in the sky and relating it to a rectangular patch of earth.
} 
ical morphology at that time, nor delineated to run in parallel with the adjacent coastline. It was, the study finds, planned to align with the rising sun on the day of Alexander's birth, July 20, 356 B.C.E. by the Julian calendar. The city was thus orchestrated along a main axial street called Canopic Road that stretched eastwest. The Canopic symbolized the extent of Alexander the Great's power and his astral divinity (Magli 2008a).

Similar findings are published in Magli's book "Secrets of the Ancient Megalithic Towns", which examined the orientation of some 38 towns in Italy. It appears that most of the Roman towns in Italy were aligned to sunrise or to the cardinal points, or were related to important sacred events. Of particular interest is the city of the 'inventor'Augustus; Augusta Praetoria Salassorum (modern Aosta) that was founded around 25 B.C.E. to celebrate the victory of this emperor. Bertarione and Magli(2013) analyzed the astronomical reference in the foundation of Aosta that includes a temple devoted to Augustus and a huge triumphal arc built along the decumanus axis. The research found that the entire town was oriented in a matter to detect Augustus' association with the 'cosmic' signs of renewal- the winter solstice and the Capricorn. Accordingly, Aosta witnessed a rigorous geometry through which its axis is oriented in a way that corresponds with the rising sun at the winter solstice. Sunrise and sunset at the winter and summer solstices may clearly be marked by sighting lines in the city.

Unfortunately, similar investigations for the Roman cities in the East provinces, especially Gerasa and Palmyra, are not made yet ${ }^{13}$. Nevertheless, and according to existing findings, González-García and Magli (2015) stress the fact that astronomy was influential in the planning of the Roman city (exceptions are of course considered in cities that featured different natural and topographical situations). Based on this astronomical hypothesis, we may suggest that the Roman streets acted as a 'cosmological denominator' with certain cardinal direction to establish connections with the cosmic order. The axial colonnades were thus transformed into an astrological symbol and their role was enhanced with the increased numbers of temples that created new axial emphasis in the urban fabric of Rome, starting with the Forum Romanum ${ }^{14}$ (Fig. 4). However, and whilst a 'physical' axis did not clearly materialize at the level of the entire city inside Rome and other Roman cities, similar approach for stressing an axial planning in Roman cities and colonies could have been achieved through the colonnaded streets. The once colonnaded open spaces of the temple portico and the forum that were acting as a forecourt to the

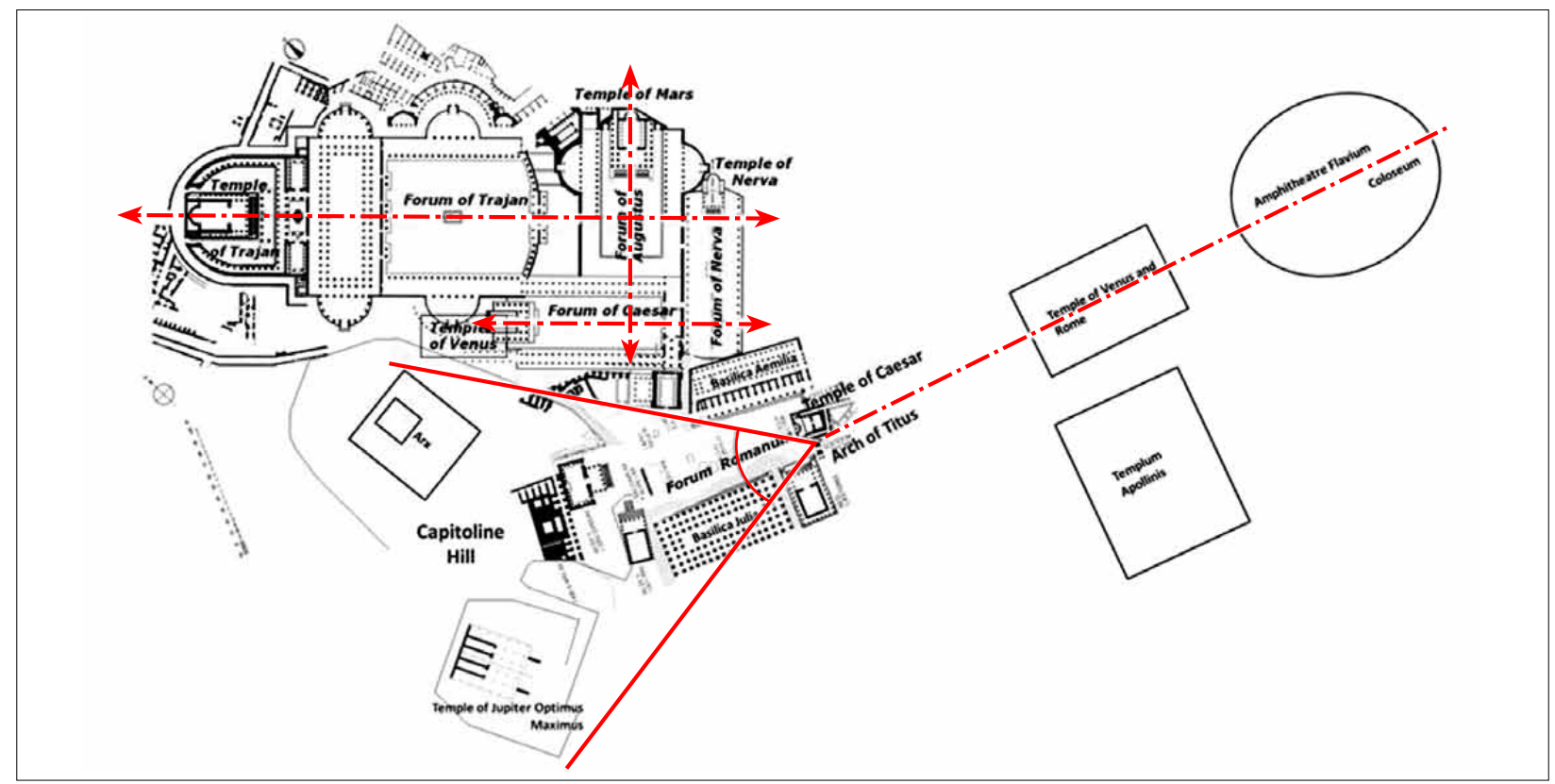

Fig. 4. Axial configuration of the temple complex at the Forum of Caesar which has been transformed into an urban language that characterized the Roman Imperial fora zone

13 Through a personal contact with Giulio Magli, he suggests that the trasversal axis to the main colonnaded street in Gerasa has an azimuth close (but not equal) to summer solstice sunset. These are preliminary findings since he does not obtain local measure of the hills which are located to the north-west of Gerasa.

14 The Forum Romanum that exhibited the Temples of Divus Julius and the Temple of Saturn at its opposite ends. Significance of this physical axis was enhanced when it was supported by a visual axis, as experienced in the Temple of Saturn, which if standing in the middle of the forum, is visually connected with the Temple of Jupiter Capitolinus on the hill above through a perspective view (i.e., visual axis). 
temple were stretched throughout the entire Roman city as a screen of columns to unfold the city's urban spaces in linear astronomical perspectives.

Along with the cosomological concepts, the colonnaded streets could have been dictated political dimensions. Whilst the axial composition of the temple(s) and its forum achieved control and astral divinity inside Rome and other Roman colonies, the dominating linear colonnaded streets could have presumably served similar purposes outside Rome, especially in the Roman East cities. Its axial morphology along with the defined (mostly Corinthian) orders suggests a canon of proportions that connects the ruler's sense of order, control, and astral divinity with those of the god's, i.e., it stands as a metaphor of the 'scared link' and the gratification of god and of man who created order in the sacred and secular worlds. To this end, the ideas about the 'Celestial archetypes' and 'symbolism of the centre' formed very important parts of political ideology of the Roman rulers and their role in bridging the secular and secular worlds. Further understanding of the interrelation between the sacred and secular worlds is enhanced if we approach the colonnaded streets through its performative role-as will be discussed in the next section.

\section{Performative interpretation to represent an empire of imperial power}

This study suggests that success of the urban design in the Roman cities was achieved because public spaces emerged as part of the functional but also the visual and psychological experience in the city. The Romans created an image of the city that invested in straight paths lined with colonnades. The colonnaded streets thus evolved with a processual quality of the spatial experience, the event structure of spatial coherence, the openness and interconnectedness of spatial structures, i.e., performative urbanism.

Performative urbanism, urban movement and the argument of eye (i.e., urban visualization) are all encompassing terms. They turn our attention to the faculty of sight, especially in cultures that believe in the gods' guardianship of their cities, as the case in the Roman culture. Personification of the city as a 'looker' within numerable sightless eyes and the idea of the gods living in the city, sharing the Romans' physical space with them, and looking upon the city are too deeply embedded in the Romans' distinctive conceptualization of their city ${ }^{15}$ (for more information see Jenkyns

\footnotetext{
${ }^{15}$ Gods have been given an anthropometric interpretation with an immortal power and resides in 'houses'. The supreme god Jupiter, is being ideologically presented in the central sight/site of Rome (the temple on the Capitoline Hill) as the 'house of god' as if the god himself (or herself in case of a goddess) is doing the 'looking' and observation.
}

2013; Rababeh 2011). Accordingly, temples (as 'houses of the gods') were mostly placed high or in the central civic forums; bringing by that the experiences of the gods (as guardians) and men (as spectators) together to create performative urbanism.

On another secular level, performative urbanism in Roman cultures implies that urban spaces in the city were able to represent an 'ideology of publicity' and the judicial and political processes in the city. Political actions and political changes, closely bound in with visible representation, were strongly expressed in the urban fabric of the Roman city through regulated processions and 'formal movement'. Similar perception for the ideology of publicity was introduced to cities outside Rome. Stirling (2006: 76) suggests "[a]n important role for art in the Roman Empire was to convey the power and accomplishments of the emperor... Triumphal arches, altars, and custom-designed fora spread outwards from Rome to major provincial cities as a way of asserting the emperor's presence at nodal points on the urban landscape, and signified a special relationship between a city that received them and the ruling power". In cases of cities featuring a colonnaded streets that is tightly connected with the triumphal arch on one side and the forum on the other side, it could be suggested that the colonnaded streets became part of this ideology and acted as a 'monumental approach' to serve processional movement. Thus, urban spaces of paths (colonnaded streets), nodes (forum) and landmarks (mainly temples) were synergistically connected with each other to create a sense of visual continuity, experiential integrity, and phenomenological involvement. By that, the colonnaded streets were transformed into a theatrical tool. To come into this urban space is to come under the 'conspectus' of the people as a matter of urban reality and to come under the power of the emperor as an imaginative truth.

According to this interpretation, location of the colonnaded streets at the centre of the city added a new technique to shape messages concerning power and dynastic links: the colonnaded streets, the emperor, and religion were perceptually interrelated with each other and made part of the daily encounters of these communities. It is an image that can be related to the monumental Egyptian avenue of sphinxes and the Processional Way that ran through the Ishtar gate. It can be also analogically compared with the bas relief from the North Palace of Ashurbanipal (669-631 B.C.E.) at Nineveh. The panel portrays the King with the royal stela set up on a path leading the pavilion and the King standing in a commanding position, proclaiming that Sennacherib was the king who had created the surrounding order (Fig. 5). He is positioned at the city gate ready to promenade along an ordered Corinthian-like 

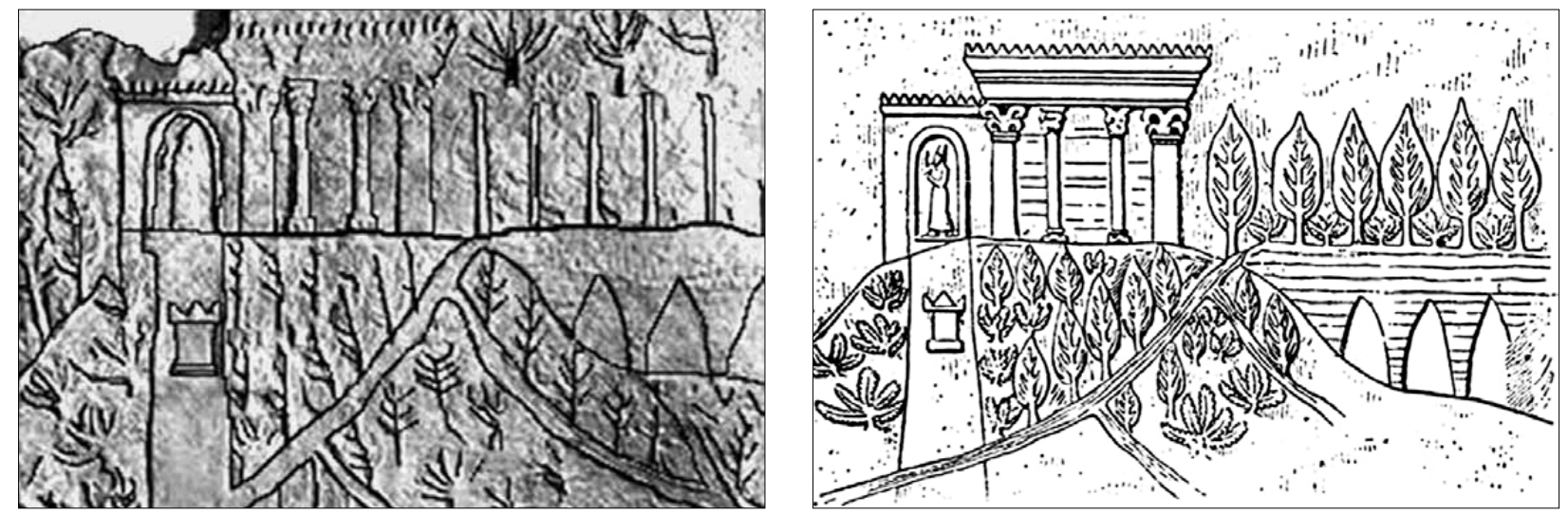

Fig. 5. Bas-relief from king Ashurbanipal's palace, representing a garden irrigated by an aqueduct, Image courtesy Oxford University Press 2013. Source: modified from http://www.megalithic.co.uk/modules.php?op=modload\&name=a312\&file=index\& do =showpic\&pid $=115357$

colonnaded walkway, connected to a colonnade of tree stems raised at the same height atop an arched aqueduct to lead to the ordered garden (Heaven) (Dalley 2013). In such means, the axial colonnade appeared as a dominating feature in the cityscape and its panoramic view. Likewise, it could be suggested that the colonnaded streets was introduced into the urban fabric of the roman cities outside Rome as an 'avenue' that gave a theatrical effect, represented imperial power, and conveyed an authoritative image to the public. In effect, the colonnaded streets were transformed from a mere 'line on a site' that facilitates the zoning of the city into a 'line of sight' and a catalyst for urban imagery and a vigorous re-examination of 'traditional' perspectives of the Roman cities. In other words, it became a fundamental expression of man's involvement in the sacred and secular worlds that coexist within the Roman city.

\section{Conclusions}

The study sought to confront the ambiguities about possible uses and meanings of the Roman colonnaded streets within Roman cities in the imperial period. A spatial reading of the colonnaded streets suggests that the colonnaded streets acted a prominent feature of Roman cities to reflect both ancient astrological beliefs, and in particular 'theories of astral divinity', and imperial ideologies, concerned with the power and accomplishments of the emperor. The colonnaded streets is thus deployed to promote political and religious cohesion and to connect the macro-cosmic design with the micro-urban design of the Roman city. It shows that, for the Romans, these two levels have so much in common and are so interrelated that we may see them as belonging to the same process of designing the urban space.
On another level, however, and perceiving the urban spaces as a representational entity made by ideological decisions and for performative reasons, the colonnaded streets have been discussed through its visual and spatial influence on the quality of the public realm, i.e., the spirit of urbanism. The colonnaded streets acquired a stage-set quality through which political ideologies were translated into spatially sensitive and imaginative urban design. It transformed the Roman city into a 'Gestalt city' that invests in the movement of the viewer to create 'imperial gaze' and encourages multiple, yet connected and analytical gazing of the Roman urbanism.

Analyzing the colonnaded streets from a spatial perspective should not suggest a preference for ideological over functional and aesthetic explanation of urban forms and a desire to understand them as purely visual symbolic expression that imply a convergent of sacred and secular meanings. Rather, our study adopts a holistic approach because we believe that it opens up at a new interpretation of the colonnaded streets that was equally utilitarian and symbolic in creating an urban cohesion in the Roman cities. It thus expands the reading of the 'image of the Roman city' as a construction with multi-layered meanings. In this regard, we refer to Smith (2007) in his distinguished work on "Form and Meaning in the Ancient Cities: A New Approach to Ancient Urban Planning". With reference to Rapoport's model for levels of meaning in the built environment, he believes that ancient rulers sought to communicate certain messages through the architecture of their cities. He thus distinguishes between three levels of meanings: high-level meanings that attribute the urban planning (especially orthogonal planning) of ancient cities to religious motives; middle-level meaning that interprets the establishment 
of towns as explicit statements of political authority; and low-level meaning that implies functional and practical ideas for surveying and laying out new cities. According to the holistic approach that has been adopted in this study, it is suggested that Roman urban landscape, and through its colonnaded streets, was able to integrate all these diverse levels of meanings. While traditional interpretations about the 'functional' and 'cultural' significances of the urban Roman features are instrumental for conveying low and middle-level meanings in the making of the Roman landscape; its astronomical and imperial interpretations open up new perspectives for considering these ancient cities as assets with 'high-level meanings'. Only in this way can we avoid a further divide in the scope of dealing with the colonnaded streets as an urban entity that enriches Roman cities as a Roman legacy until these days.

\section{Acknowledgements}

The authors would like to thank Giulio Magli, the archaeo-astronomer at the Politecnico of Milan for his support in providing us with some crucial materials and insightful thoughts about the astronomical interpretation for the colonnaded streets. We are thankful to Architect Shereen Athamneh for helping in the drawings. Our special thanks to the anonymous reviewers for their constructive comments that significantly improved the final presentation of the paper.

\section{References}

Bertarione, S. V.; Magli, G. 2013. Under Augustus sign: the role of Astronomy in the foundation of Augusta Praetoria Salassorum [onine], [16 November 2014]. Xiv:1311.7282 [physics.hist-ph]. Available from Internet: http://arxiv.org/ abs/1311.7282

Bosanquet, R. C. 1915. Greek and Roman towns: II. Town planning in Syria, The Town Planning Review 6(2): 76, 101-113.

Burns, R. A. 2011a. Colonnaded streets in the cities of the East under Rome. North Ryde, N. S. W.: Macquarie University.

Burns, R. A. 2011b. The colonnaded axes of the cities of the Decapolis and southern Syria in the Roman imperial period - romanization or localization?, ARAM 23(1\&2): $447-465$

Butcher, K. 2003. Roman Syria and the Near East. London: The British Museum Press.

Cavaglieri, G. 1949. Outline for a history of city planning. from prehistory to the fall of the Roman empire: IV. Etruscan and Roman,Journal of the Society of Architectural Historians 8(3/4):27-42. http://dx.doi.org/10.2307/987434

Coulton, J. 1976. The architectural development of the Greek Stoa. Oxford: Clarendon.

Dalley, S. 2013. The mystery of the hanging garden of Babylion: an elusive world wonder traced. Oxford: Oxford University Press.
Eliade, M. 1954. Cosmos and history: the myth of the eternal return. Translated by R. W. Trask. New York: Harper \& Brothers Publishers.

González-García, A.; Magli, G. 2015. Roman city planning and spatial organization, in Handbook of archaeoastronomy and ethnoastronomy. New York, USA: Springer, 1644-1650. http://dx.doi.org/10.1007/978-1-4614-6141-8_164

Hadidi, A. 1970. The Roman forum at Amman. Michigan: University Microfilms.

Haverfield, F. 1913. Ancient town planning. Oxford: Clarendon Press.

Jenkyns, R. 2013. God, space and the city in the Roman imagination. Oxford: Oxford University Press.

Jones, A. 2015. Transmission of Babylnian astronomy to other cultures, in C. Ruggles (Ed.). Handbook of archaeoastronomy and ethnoastronomy. New York, USA: Springer, 1877-1882. http://dx.doi.org/10.1007/978-1-4614-6141-8_194

Khouri, R. 1986 Jerash: a frontier city of the Roman east. London, New York: Longman.

Kostof, S. 1991. The city shaped: urban patterns and meanings through history. UK: Thames \& Hudson.

Kraeling, C. 1938. Gerasacity of the Decapolis. New Haven: The American of Oriental Research.

MacDonald, W. L. 1982. The architecture of the Roman empire: an urban appraisal, vol. II. New Haven: Yale University Press.

MacDonald, W. L. 1984. Roman urbanism, Journal of Architectural Education 41(3): 29-32. http://dx.doi.org/10.1080/10464883.1988.10758486

MacDonald, W. 1986. The architecture of the Romanempire II. New Haven, Conn.: Yale University Press.

Magli, G. 2008a. On the orientation of Roman towns in Italy, Oxford Journal of Archeology 27 (1): 63-71.

Magli, G. 2008b. On the origin of the Roman idea of town: geometrical and astronomical references, in J. Vaiskunas (Ed.). ArchaeologiaBaltica: astronomy and cosmology in folk traditions and cultural heritage. Klaipeda: Klaipeda University Press, 149-154.

Mango, M. 2001. The porticoed street at Constantipole, in N. Necipoğlu (Ed.). Byzantine Constantipole: monuments, topography and everyday life. Leiden: Brill, 29-52.

Mansuelli, G. A. 1979. The Etruscan city,in Italy before the Romans: the iron age, orientalizing and Etruscan periods. London: Academic Press Inc., 353-371.

Morgan, M. H. 1914. Vitruvius: the ten books on architecture. Cambridge: Harvard University Press.

Owens, E. J. 1991. The city in the Greek and Roman world. London: Routeledge.

Palet, J. M.; Orengo, H. A. 2011. The Roman centuriated landscape: conception, genesis, and development as inferred from the ager tarraconensis, American Journal of Archaeology 115(3): 383-402.

http://dx.doi.org/10.3764/aja.115.3.0383

Plommer, H. 1956. Ancient and classical architecture. London: Longmans, Green and Co.

Pregill, P.; Volman, N. 1999. Landscapes in history: design and planning in the Eastern and Western traditions. New York: John Wiley. 
Rababeh, S. 2011. The temples of Zeus and Artemis and their relation to the urban context of Gerasa, ARAM23: 177-189.

Rochberg, F. 2010. Babylonian astral science in the Hellenistic world: reception and transmission, CAS LMU e series (4): $1-11$.

Rostovtzeff, M. 1926. The social and economic history of the Roman empire. Oxford: University of Oxford Press.

Ruggles, C. 2014. Theme [online], [cited 16 November 2014]. Astronomy and World Heritage Webportal. Available from Internet: http://www.cliveruggles.net/

Ruggles, C. 2015. Greco-Roman astrology, in Ruggles (Ed.). Hndbook of archaeoastronomy and ethnoastronomy. New Yotk, USA: Springer, 1629-1336.

Sear, F. 1982. Roman architecture. London: Batsfor Acdemic and Educational Limited.

Segal, A. 1975. The planning of the cities along the Via Traiana Nova in the Roman period. Jerusalem: The Hebrew University.

Segal, A. 1981. Roman cities in the province of Arabia, Journal of the Society of Architectural Historians 40(2): 108-121. http://dx.doi.org/10.2307/989724

Segal, A. 1997. Colonnaded streets, in From function to monument: urban landscape of Roman Palestine, Syria and provincia Arabia. Oxford: Oxbow Books, 5-54.

Smith, M. E. 2007. Form and meaning in the earliest cities: a new approach to ancient urban planning, Journal of Planning History 6(1): 3-47. http://dx.doi.org/10.1177/1538513206293713

Stamper, J. W. 2005. The architecture of Roman temples: the republic to the middle empire. Cambridge: Cambridge University Press.

Starte, M. 2005. The Middle East under Rome. Cambridge: Harvard University Press.

Stirling, L. 2006. Art, architecture, and archeology in the Roman empire, in D. S. Potter (Ed.). A companion to the Roman empire. Malden, USA: Blackwell Publishing Ltd., 75-97.

http://dx.doi.org/10.1002/9780470996942.ch5

Tomlinson, R. 1992. From Mycenae to Constantinople. The evolution of the ancient city. London, New York: Routledge. http://dx.doi.org/10.4324/9780203412909

Ward-Perkins, J. B. 1974. Cities of ancient Greece Italy. New York: George Brazilier.

Ward-Perkins, J. B. 1979. Roman architecture. New York: Electa/ Rizzoli.

Woloch, G. 1983. Roman cities. WI: The University of Wiscinsin Press.

Zanker, P. 2000. The city as symbol: Rome and the creation of an urban image, Journal of Roman Archaeology 38: 25-41.

Zeyadeh, A. 1985. An archaeological assessment of the six cities in al-Urdun: from the fourth to the mid-eighth century A.D.: Master thesis. Jordan: Yarmouk University.

\section{SHAHER RABABEH}

Department of Architectural Engineering, Hashemite University, Zarqa, Jordan. E-mail: srababeh@hu.edu.jo

Shaher Rababeh, the author of "How Petra was Built", is an associate professor of architecture and construction, the founder and the former chair of the Department of Architec- ture (2005-2011), the founder and the director of the Department of Engineering Projects (2007 - present), the vice dean of the Faculty of Engineering (2011-2012) and the dean of the Faculty of Engineering at the Hashemite University, Jordan (Feb 2012 - present). He received his BSc in Architectural Engineering from Yarmouk University, Jordan in 1987. From the University of Oxford he was awarded his MSt in Classical Architecture and DPhil in Architectural Construction Techniques and Methods of Design, in 2005. Thereafter, he has been associated with the Faculty of Engineering at the Hashemite University for nine years. During that time, he has established the department of Architecture and the Engineering Projects Unit. His approach to research and management is founded in his education and the realities of working as a designer for 14 years before getting the DPhil, and in the main values common to any organisation: respect, team spirit, transparency and creativity.

\section{RAMA AL RABADY}

Department of Architectural Engineering, Hashemite University, Zarqa, Jordan.E-mail: ramarabady@gmail.com

Rama Al Rabady is an Associate Professor in the Department of Architectural Engineering at the Hashemite University in Zarqa, Jordan. She earned her three degrees in Architecture: a B.Sc. from Jordan University of Science and Technology; an M.Sc. from the University of Jordan; and a PhD from Texas A\&M University. Her research interests include integrated heritage management, good governance in heritage planning, spatial conservation and tourism development in urban contexts, and advanced technology applications in heritage documentation and management.

\section{SHATHA ABU-KHAFAJAH}

Department of Architectural Engineering, Hashemite University, Zarqa, Jordan. E-mail: shathaa116@gmail.com

Shatha Abu-Khafajah is an Assistant Professor in the Department of Architectural Engineering at the Hashemite University in Zarqa, Jordan. With her B.Sc. in Architectural Engineering and her M.A. in Archaeology, both from Jordan University, she wrote her thesis on the documentation and conservation of architectural heritage in Jordan. She earned her $\mathrm{PhD}$ in Cultural Heritage Management from Newcastle University in the U.K. Her research focuses on meanings and uses of cultural heritage, cultural sustainability, and the intersection between anthropology, archaeology, architecture, and urban landscape in different contexts. 